\title{
Comparison of fattening performance, carcass characteristics, and egg quality characteristics of Japanese quails with different feather colors
}

\author{
Hakan Inci ${ }^{1}$, Bunyamin Sogut ${ }^{1}$, Turgay Sengul ${ }^{1}$, Ahmet Yusuf Sengul ${ }^{1}$, Mehmet Resit Taysi ${ }^{1}$ \\ ${ }^{1}$ Bingol University, Bingol, Turkey.
}

\begin{abstract}
The objective of this study was to compare fattening performance, carcass traits, and egg quality of Japanese quails with different feather colors (white, dark brown, golden, and wild-type). In the study, 360 one-day-old quail chicks with 4 different feather colors were used as animal material. Quails were fed ad libitum for 42 days to determine fattening performance and carcass traits. To determine egg traits, 48 hens from each group, in a total of 192, were selected and caged according to feather color. Eggs were collected for four consecutive weeks and egg quality characteristics were measured. Different feather colors had a significant effect on live weight, feed intake, feed conversion ratio, and carcass characteristics. Significant differences between the groups were detected for egg weight, specific gravity, shape index, shell weight, albumen weight, yolk weight, albumen index, and yolk index. Japanese quails with all four feather colors can be reared depending on the choice. However, due to lower feed conversion ratio, white-feathered quails may be preferred for meat production purposes. Color variations should be considered when selecting quails.
\end{abstract}

Key Words: Coturnix coturnix japonica, feather color, egg, phenotypic characteristics, quail

\section{Introduction}

As it is well known, Japanese quail is today the smallest poultry species kept for eggs and meat on some farms (Crawford, 1990; Minvielle, 1998). It is also accepted as a laboratory animal widely used for biological and genetic studies because of its small body size, resistance to diseases, rapid growth, easily handling, and possibility of using a large number of animals in a limited space (Koçak, 1985; Narayan et al., 1998; Y1ld1z and Kesici, 1999; Minvielle et al., 2007; Tarhyel et al., 2012a).

The growth performance and number of color mutations reported in quail are still very limited compared with the number reported in other poultry species. Neither mutation nor performance traits have been studied in extenso yet (Robertson et al., 1943; Somes, 1979; Cheng and Kimura, 1990). Most of the plumage color mutations found in Japanese quail have been merely documented and described (Merat et al., 1981; Tsudzuki, 1995; Nakane and Tsudzuki, 1998; Minvielle et al., 1999, 2003). One Japanese quail

Received April 27, 2015 and accepted August 5, 2015 Corresponding author: hakaninci2565@hotmail.com http://dx.doi.org/10.1590/S1806-92902015001100003

Copyright (C) 2015 Sociedade Brasileira de Zootecnia. This is an Open Access article distributed under the terms of the Creative Commons Attribution License (http://creativecommons.org/licenses/by/4.0/), which permits unrestricted use, distribution, and reproduction in any medium, provided the original work is properly cited. plumage-color mutant has been reported as white (Roberts et al., 1978), while other authors (Somes, 1976; Truax and Johnson, 1979; Cheng and Kimura, 1990; Minvielle et al., 2002) have called it 'recessive white'.

Information about growth performance and plumagecolor mutations is insufficient to assess their use in commercial production. Correlated effects of Japanese quail plumage color genetic variants on performance traits have only been studied for a few mutations, such as the roux mutation, which can be used for auto-sexing at $1 \mathrm{~d}$ of age (Minvielle et al., 1999); the recessive white gene (Petek et al., 2004); the curly mutation, which is associated with increased live weight (Minvielle et al., 2005); the Dominant Lethal Yellow mutation (Minvielle et al., 2007); genetic analysis of brown plumage color in quail (Yilmaz and Çağlayan, 2008); and genes determining yellow and dotted white plumage patterns in Japanese quail (Yildız and Kesici, 1997).

Results of some studies indicated that white-feathered quail had less body weight then the wild-type (Yildiz and Kesici, 1997; Petek et al., 2004; Minvielle et al., 2005; Yilmaz and Çağlayan, 2008). In the literature, information regarding the effects of feather color on growth performance in quail is measurable. This study was conducted to determine the fattening performance, carcass characteristics, and egg quality characteristics of Japanese quails with different feather colors. 


\section{Material and Methods}

In the study, 360 one-day-old Japanese quail (Coturnix coturnix japonica) chicks with four different feather colors (white, dark brown, golden and wild-type) were used. Hatched chicks were raised together for two weeks and then separated based on their feather colors. Chicks with the same feather color were divided into three groups ( 30 chicks in each) and caged, with the temperature kept at 35 to $37^{\circ} \mathrm{C}$.

This study was approved by the Bingol University Local Ethical Committee on Animal Experiments, dated 05.26.2014, Decision No 09/03.

Commercial quail ration was used supplying the approximate quail requirement for dry matter, energy, and other nutrients. Chicks received a mash grower feed containing $23 \%$ crude protein and $3,100 \mathrm{kcal} / \mathrm{kg}$ metabolizable energy (ME); feed and water were provided ad libitum throughout the experiment. The diet was formulated according to the NRC (1994) guidelines (Table 1). After 6 weeks of age, quails were fed a layer-quail feed consisting of $23 \%$ crude protein and 2,800 kcal $/ \mathrm{kg} \mathrm{ME}$ to determine egg quality characteristics.

The day-old chicks were raised in a brooder for two weeks and then the divided into the groups based on their color and housed in multilayer breeding cages. Quails were fed for 42 days to determine fattening performance and carcass characteristics. After the fattening period, 80 birds (10 males and 10 females from each color group) were slaughtered. During the study, weekly live weight gain, feed intake, feed conversion ratio (FCR), mortality rate,

Table 1 - Composition of quail feeds used in the experiment (\%)

\begin{tabular}{lcc}
\hline & $\begin{array}{c}\text { Starter feed } \\
(0-6) \text { weeks }\end{array}$ & $\begin{array}{c}\text { Grower feed } \\
\text { (After 6 weeks) }\end{array}$ \\
\hline Ingredient, \% & 48.0 & 46.5 \\
Corn & 6.0 & 6.0 \\
Wheat & 33.0 & 34.0 \\
Soybean meal & 4.0 & 4.5 \\
Vegetable oil & 4.0 & 4.0 \\
Fish meal & 2.5 & 2.5 \\
Meat-bone meal & 0.5 & 0.5 \\
Dicalcium phosphate & 1.0 & 1.0 \\
Limestone & 0.2 & 0.2 \\
Methionine & 0.1 & 0.1 \\
Lysine & 0.4 & 0.4 \\
Salt & 0.3 & 0.3 \\
Vitamin + mineral premix ${ }^{1}$ & & 23 \\
Calculated value & 23 & 2,800 \\
Crude protein, \% & 3,100 & \\
Metabolic energy, kcal/kg & & \\
\hline
\end{tabular}

${ }^{1}$ Added per kg: vit. A - $11.00 \mathrm{IU}$; vit. D - 32,000 IU; vit. B1- $2.5 \mathrm{mg}$; vit. B6 - $1.25 \mathrm{mg}$; vit. B12 - $0.01 \mathrm{mg}$; $\alpha$-tocopheryl acetate $-50 \mathrm{mg}$; biotin - $0.06 \mathrm{mg}$; vit. $\mathrm{K}-2.5 \mathrm{mg}$; niacin $-15 \mathrm{mg}$; folic acid $-0.30 \mathrm{mg}$; pantothenic acid $-10 \mathrm{mg}$; choline $-600 \mathrm{mg}$; Mn - 60 mg; Fe - 50 mg; Zn - 15 mg; I - 0.5 mg; Co - 0.5 mg. and carcass characteristics (carcass weight, carcass yield, breast weight, breast ratio, thigh weight, thigh ratio) were determined. The feed conversion ratio was calculated as feed intake/live weight gain.

A total of 192 females (48 females from each color group) were used to determine egg yield characteristics. A total of 1,536 eggs - 384 eggs from each group - were collected for four consecutive weeks. Egg weight, shape index, specific gravity, shell thickness, shell weight, albumen index, yolk index, albumen weight, yolk weight, and Haugh unit of the collected eggs were measured.

Eggs were weighed individually on a precision digital scale (0.01 precision). After rinsing the eggshell for several times, washed shells were left for $8 \mathrm{~h}$ at ambient temperature, dried, and individually weighed, and their relative weights were calculated as a function of the egg weight. Shells from three eggs per replicate were taken to measure thickness in three equatorial regions of each shell using a manual micrometer.

The yolk of the cracked egg was separated from the albumen and then weighed. The albumen weight was calculated by the following equation: egg weight - (shell weight + yolk weight). Shape index was calculated as egg width/egg length $\times 100$ (Marks and Kiney, 1964; Y1ldiz, 1983; Stadelman, 1986; Erbaş and Olmuş, 2006; İnci et al., 2015). Haugh unit was calculated by measuring the yolk height with a three-legged micrometer, using the method proposed by Stadelman (1986).

During the study, live weight was determined individually, whereas feed intake was determined on the group basis by weekly weighing. The diets were in powdered form and extra attention was paid to provide animals with clean water.

Data from studied characteristics were analyzed by using the Proc GLM procedure of SAS (Statistical Analysis System, 1998) statistical package software and an Orthogonal Polynomial test was used to compare the difference between means.

\section{Results}

No significant differences were observed among the groups for LW at the first week of age (Table 2). However, the $\mathrm{LW}$ of quail from the four plumage color variant groups was statistically different $(\mathrm{P}<0.01)$ at the end of the 2 nd week of age. The highest LW of quails was observed in the wild-type group. Variations between the average LW of groups at the end of the third week were significant $(\mathrm{P}<0.01)$ for the female $(\mathrm{F})$ and male + female (Mix) groups, but not significant for males (M). At the 4th, 5th, 
and 6th weeks of the trial, variations in LW between the groups were significant $(\mathrm{P}<0.01)$ for both sexes and for Mix $(\mathrm{P}<0.05, \mathrm{P}<0.01)$. In these weeks, the wild-type group had relatively better performance. Consistent with other weeks, the highest live weight values were obtained by the wildtype quails. No significant color $\times$ sex interaction occurred for live weight.

The main effects of feather color variants on cumulative feed intake, feed conversion ratio, and standard errors were statistically different until the end of the growing period (Table 3).

In the initial four-week period, the average feed intake for the white, dark brown, golden and wild-type groups was 421.5, 390.8, 405.4, and $455.8 \mathrm{~g}$, respectively. Color variation affected feed intake significantly $(\mathrm{P}<0.01)$, and the group that consumed the lowest amount of feed was dark brown. Significant differences in the FCR of the groups were observed in the $0-4$ week period $(\mathrm{P}<0.05)$, and the group with the highest FCR was dark brown.

In the 0 -5-week period, there were significant $(\mathrm{P}<0.01)$ differences in feed intake among groups; the group that consumed the highest and the lowest amounts of feed were wild-type and dark brown, respectively. The FCR of the quails in the 0-5-week period was significantly affected $(\mathrm{P}<0.05)$ by the color variant, and the groups with the highest FCR ratios were dark brown and golden.

In the 0-6-week period, feed intake values for the white, dark brown, golden and wild-type groups were 727.3, 694.2,

Table 2 - Live weight averages at different weeks (g) and standard errors ( $\mathrm{X} \pm \mathrm{Sx})$ of male and female quails with different feather colors

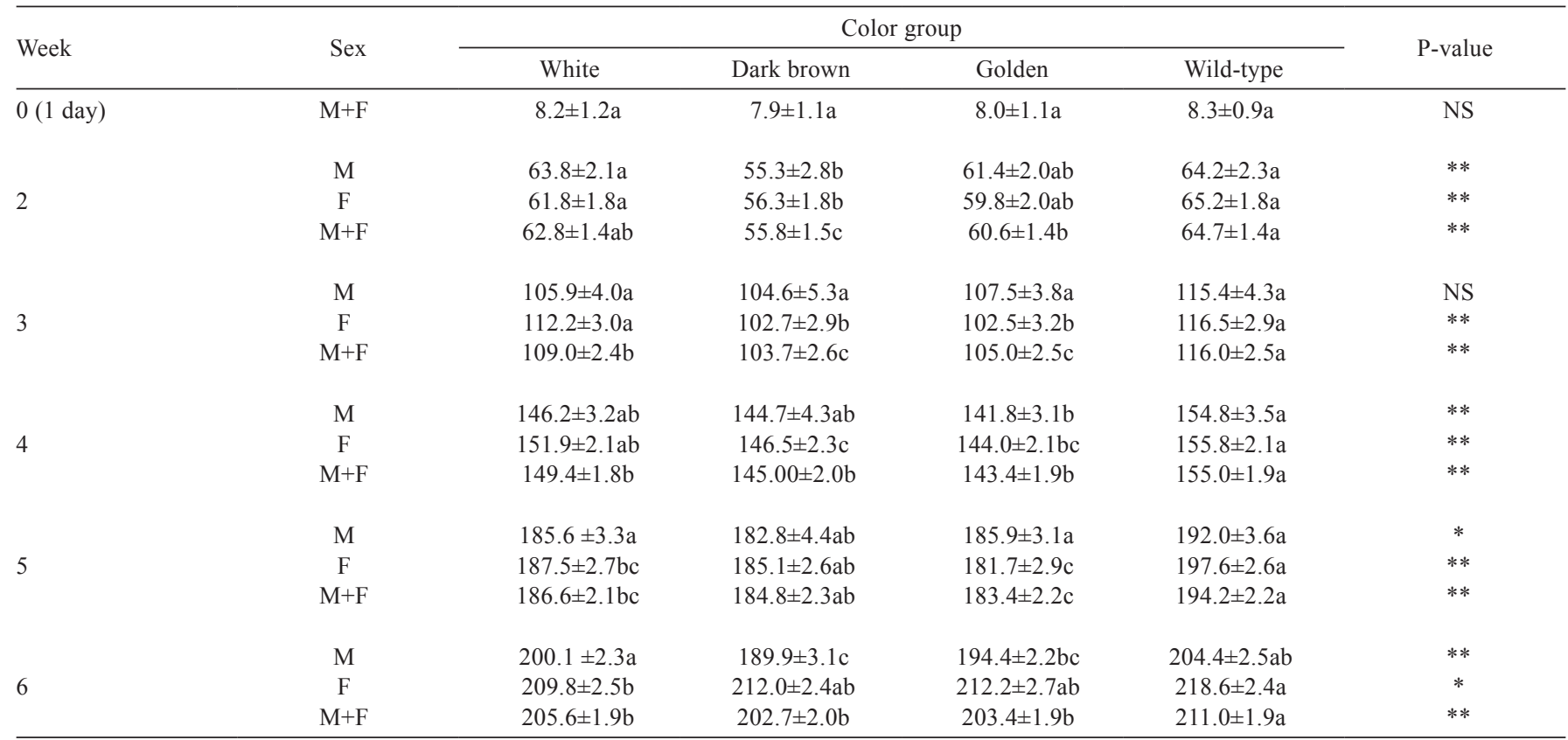

Mean \pm standard deviation.

a, b, c - differences between means in the same row with different letters are significant.

$\mathrm{M}$ - male; F - female; M+F - mixed (female + male); NS - not significant.

$* \mathrm{P}<0.05, * * \mathrm{P}<0.01$.

Table 3 - Cumulative feed intake, feed conversion ratio, and standard errors for different feather color groups $(\mathrm{X} \pm \mathrm{Sx})$

\begin{tabular}{|c|c|c|c|c|c|}
\hline \multirow{2}{*}{ Week } & \multicolumn{4}{|c|}{ Color group } & \multirow{2}{*}{ P-value } \\
\hline & White & Dark brown & Golden & Wild-type & \\
\hline \multicolumn{6}{|c|}{ Feed intake $(\mathrm{g})$} \\
\hline $0-4$ & $421.5 \pm 2.9 \mathrm{~b}$ & $390.8 \pm 4.1 \mathrm{dc}$ & $405.4 \pm 5.5 \mathrm{c}$ & $455.8 \pm 5.4 \mathrm{a}$ & $* *$ \\
\hline $0-5$ & $601.5 \pm 5.5 b$ & $554.8 \pm 4.2 \mathrm{c}$ & $565.3 \pm 5.8 \mathrm{c}$ & $638.3 \pm 6.9 \mathrm{a}$ & $* *$ \\
\hline $0-6$ & $727.3 \pm 8.2 b$ & $694.2 \pm 6.2 \mathrm{dc}$ & $705.7 \pm 4.2 \mathrm{c}$ & $769.3 \pm 8.4 \mathrm{a}$ & $* *$ \\
\hline \multicolumn{6}{|c|}{ Feed conversion ratio $(\mathrm{g} / \mathrm{g})$} \\
\hline $0-4$ & $2.8 \pm 0.6 \mathrm{a}$ & $2.7 \pm 0.5 \mathrm{ab}$ & $2.8 \pm 0.2 \mathrm{a}$ & $3.0 \pm 0.5 \mathrm{a}$ & $*$ \\
\hline $0-5$ & $3.2 \pm 0.1 \mathrm{a}$ & $3.0 \pm 0.1 \mathrm{ab}$ & $3.1 \pm 0.1 \mathrm{ab}$ & $3.3 \pm 0.1 \mathrm{a}$ & $*$ \\
\hline $0-6$ & $3.5 \pm 0.1 \mathrm{~b}$ & $3.4 \pm 0.1 \mathrm{~b}$ & $3.5 \pm 0.1 \mathrm{~b}$ & $3.7 \pm 0.1 \mathrm{a}$ & $* *$ \\
\hline
\end{tabular}

Mean \pm standard deviation.

$\mathrm{a}, \mathrm{b}, \mathrm{c}-$ differences between means in the same row with different letters are significant.

$* \mathrm{P}<0.05, * * \mathrm{P}<0.01$. 
705.7, and $769.3 \mathrm{~g}$, respectively. The color variant affected feed intake and the differences among the group means were significant $(\mathrm{P}<0.01)$. It was observed that the wildtype group consumed more feed than the other groups. The FCR of the groups in the 0 -6-week period was significantly affected $(\mathrm{P}<0.01)$ by the color variant, and the wild-type group had a lower FCR than the three other groups.

Quails belonging to different feather color groups were slaughtered at the end of the six-week fattening period and their carcass characteristics (Table 4) were determined.

Significant differences occurred $(\mathrm{P}<0.01, \mathrm{P}<0.05)$ among mean values for characteristics such as carcass weight, carcass yield, breast weight, etc. between male and female quails in the feather color groups. The wild-type group had higher values than the others. With respect to thigh weight and thigh ratio, significant differences were detected between males of different groups, whereas no significant difference was found between the females. With respect to breast ratio, the differences between the females were significant $(\mathrm{P}<0.01)$, while the differences between the males were not significant.

During the six-week fattening period and 12-week laying period, the effect of the feather color variant on vitality values was insignificant. The mortality rates for white, dark brown, golden and wild-type groups were $6.6 \%, 7.7 \%, 6.6 \%$, and $5.5 \%$, respectively.

To determine egg quality characteristics, eggs were collected for four consecutive weeks, beginning at the 7th week of age. Characteristics such as egg weight, specific gravity, shape index, shell weight, shell thickness, albumen weight, yolk weight, albumen index, yolk index and Haugh unit were measured (Table 5).

Upon examining quality characteristics of eggs collected from quails with different feather colors, the differences between groups were significant $(\mathrm{P}<0.01$, $\mathrm{P}<0.05$ ) except for shell thickness and Haugh unit. The color variant affected egg weight, and the highest value $(13.16 \mathrm{~g})$ was obtained by the wild-type group. Similar results were obtained for specific gravity, shape index, shell weight, albumen weight, yolk weight, albumen index and yolk index.

\section{Discussion}

In this study, comparing fattening performance, carcass characteristics, and egg quality characteristics among the quails with different feather colors, at the end of the sixweek fattening period, the wild-type group had significantly higher LW averages after the 3rd week. Minvielle et al. (1999) determined that the difference in quail feather color had a significant effect on live weight and the wild-type group had higher live weight. Similarly, Genchev et al. (2008), Oguz and Minvielle (2001), and Marks (1990) reported that differences in quail feather color had a significant effect on live weight and the wild-type group had heavier live weight. In their study to compare live weight of white-colored and wild-type quails, Tarhyel et al. (2012b) reported that the feather color had a significant $(\mathrm{P}<0.05)$ effect on live weight, but the white-colored group

Table 4 - Carcass characteristics and standard errors for six-week-old male and female quails with different feather colors $(\mathrm{X} \pm \mathrm{Sx})$

\begin{tabular}{|c|c|c|c|c|c|c|}
\hline \multirow{2}{*}{ Trait } & \multirow{2}{*}{ Sex } & \multicolumn{4}{|c|}{ Color group } & \multirow{2}{*}{ P-value } \\
\hline & & White & Dark brown & Golden & Wild-type & \\
\hline \multirow[t]{2}{*}{ Carcass weight (g) } & $\mathrm{F}$ & $129.5 \pm 2.8 b$ & $129.0 \pm 2.2 b$ & $127.4 \pm 2.8 b$ & $138.0 \pm 2.2 \mathrm{a}$ & $* *$ \\
\hline & $\mathrm{M}$ & $143.0 \pm 2.3 \mathrm{ab}$ & $148.0 \pm 3.1 \mathrm{a}$ & $141.4 \pm 2.3 \mathrm{ab}$ & $147.0 \pm 2.1 \mathrm{a}$ & $*$ \\
\hline \multirow[t]{2}{*}{ Carcass yield (\%) } & $\mathrm{F}$ & $64.5 \pm 0.07 \mathrm{cb}$ & $68.3 \pm 0.07 b$ & $65.5 \pm 0.07 \mathrm{cb}$ & $71.1 \pm 0.07 \mathrm{a}$ & $* *$ \\
\hline & M & $68.2 \pm 0.02 \mathrm{ab}$ & $70.1 \pm 0.02 \mathrm{a}$ & $66.3 \pm 0.02 b$ & $70.0 \pm 0.02 \mathrm{a}$ & $* *$ \\
\hline \multirow[t]{2}{*}{ Breast weight (g) } & $\mathrm{F}$ & $50.3 \pm 1.1 \mathrm{a}$ & $49.5 \pm 1.1 \mathrm{ab}$ & $48.9 \pm 1.1 \mathrm{ab}$ & $52.1 \pm 1.1 \mathrm{a}$ & $*$ \\
\hline & M & $60.1 \pm 2.4 \mathrm{a}$ & $58.7 \pm 2.3 \mathrm{ab}$ & $53.2 \pm 2.4 \mathrm{bc}$ & $63.5 \pm 2.3 \mathrm{a}$ & $* *$ \\
\hline \multirow[t]{2}{*}{ Drumstick weight $(\mathrm{g})$} & $\mathrm{F}$ & $29.5 \pm 1.2 b$ & $29.6 \pm 1.2 b$ & $31.2 \pm 1.2 \mathrm{~b}$ & $34.4 \pm 1.2 \mathrm{a}$ & $* *$ \\
\hline & M & $32.6 \pm 3.0 \mathrm{a}$ & $32.1 \pm 3.0 \mathrm{a}$ & $32.2 \pm 3.0 \mathrm{a}$ & $33.1 \pm 3.0 \mathrm{a}$ & NS \\
\hline \multirow[t]{2}{*}{ Breast ratio $(\%)$} & $\mathrm{F}$ & $39.0 \pm 1.6 \mathrm{a}$ & $38.3 \pm 1.6 \mathrm{a}$ & $38.3 \pm 1.6 \mathrm{a}$ & $37.7 \pm 1.6 \mathrm{a}$ & NS \\
\hline & M & $42.0 \pm 1.1 \mathrm{a}$ & $39.6 \pm 1.2 \mathrm{ab}$ & $37.5 \pm 1.1 \mathrm{bc}$ & $43.1 \pm 1.2 \mathrm{a}$ & $* *$ \\
\hline \multirow[t]{2}{*}{ Drumstick ratio $(\%)$} & $\mathrm{F}$ & $23.0 \pm 1.4 \mathrm{ab}$ & $23.0 \pm 1.5 \mathrm{ab}$ & $24.5 \pm 1.4 \mathrm{a}$ & $25.0 \pm 1.5 \mathrm{a}$ & $*$ \\
\hline & M & $22.9 \pm 1.3 \mathrm{a}$ & $22.1 \pm 1.2 \mathrm{a}$ & $23.0 \pm 1.3 \mathrm{a}$ & $22.5 \pm 1.2 \mathrm{a}$ & NS \\
\hline
\end{tabular}

Mean \pm standard deviation.

$\mathrm{a}, \mathrm{b}, \mathrm{c}$ - differences between means in the same row with different letters are significant.

$\mathrm{M}$ - male; F - female; NS - not significant.

$* \mathrm{P}<0.05, * * \mathrm{P}<0.01$. 
Table 5 - Internal and external quality characteristics of eggs from quails with different feather colors

\begin{tabular}{|c|c|c|c|c|c|}
\hline \multirow[b]{2}{*}{ Trait } & \multicolumn{4}{|c|}{ Color group } & \multirow{2}{*}{ P-value } \\
\hline & White & Dark brown & Golden & Wild-type & \\
\hline Egg weight (g) & $11.65 \pm 0.14 \mathrm{c}$ & $12.04 \pm 0.15 b c$ & $11.96 \pm 0.15 \mathrm{c}$ & $13.16 \pm 0.14 \mathrm{a}$ & $* *$ \\
\hline Shape index (\%) & $78.4 \pm 0.02 \mathrm{ab}$ & $78.3 \pm 0.02 \mathrm{ab}$ & $77.9 \pm 0.02 b$ & $79.0 \pm 0.02 \mathrm{a}$ & $*$ \\
\hline Shell weight (g) & $0.85 \pm 0.01 \mathrm{~b}$ & $0.82 \pm 0.01 \mathrm{c}$ & $0.81 \pm 0.01 \mathrm{c}$ & $0.90 \pm 0.01 \mathrm{a}$ & $* *$ \\
\hline Shell thickness (mm) & $0.246 \pm 0.01 \mathrm{a}$ & $0.247 \pm 0.01 \mathrm{a}$ & $0.248 \pm 0.01 \mathrm{a}$ & $0.246 \pm 0.01 \mathrm{a}$ & NS \\
\hline Albumen index (\%) & $9.75 \pm 0.26 \mathrm{ab}$ & $9.64 \pm 0.29 \mathrm{ab}$ & $9.86 \pm 0.28 \mathrm{ab}$ & $10.01 \pm 0.36 \mathrm{a}$ & $*$ \\
\hline Yolk index (\%) & $44.37 \pm 0.56 \mathrm{ab}$ & $43.41 \pm 0.89 \mathrm{ab}$ & $44.56 \pm 0.73 \mathrm{ab}$ & $45.89 \pm 0.39 \mathrm{a}$ & $*$ \\
\hline Haugh unit & $86.43 \pm 0.65 \mathrm{a}$ & $86.45 \pm 0.71 \mathrm{a}$ & $86.85 \pm 0.70 \mathrm{a}$ & $86.43 \pm 0.65 a$ & NS \\
\hline
\end{tabular}

Mean \pm standard deviation.

$\mathrm{a}, \mathrm{b}, \mathrm{c}$ - differences between means in the same row with different letters are significant.

NS - not significant.

$* \mathrm{P}<0.05, * * \mathrm{P}<0.01$

had a lower live weight. Feather color variations affected $(\mathrm{P}<0.01)$ feed intake and feed conversion ratios at the end of the fattening period. The wild-type group had the highest feed intake, whereas the dark brown group had the lowest feed intake. As for FCR, the wild-type group had the lowest value. However, differences between the FCR of the groups were not significant. The effect of feather color differences on vitality rates was not significant. Mortality rates were similar for all groups. When comparing carcass weight, carcass yield, and carcass parts of the feather color groups, significant $(\mathrm{P}<0.01, \mathrm{P}<0.05)$ variations in general and higher value in the wild-type group than others were observed. The results of the present work are similar to the findings of a depressive effect of the recessive white-plumage color on growth rate in quail (Minvielle et al., 2002; Petek et al., 2004) and chickens (Fox and Smyth, 1982). The wild-type quail had a higher body weight than the white type throughout the growing period. Differences for body weight due to breeder age are established at two weeks of age and lasted until six weeks of age. In terms of body weight, the differences between wild-type and white, dark brown, and golden quail were 5.4, 8.3, and $7.6 \mathrm{~g}$, respectively. This result is similar to findings of Yannakopoulos and Tserveni-Gousi (1987) and Tserveni-Gousi (1987). White-color quails had lighter LW than the wild-type. This led to the conclusion that the depressive effect of the recessive white on body weight was similar regardless of the quail age.

As expected, the mortality rate of the white-type quail was higher than that of the wild-type. This result is similar to a previous report for a different color mutation (Tsudzuki, 1995; Petek et al., 2004). Carcass characteristics affected by feather color agree with results of Marks (1990), Minvielle et al. (1999), Oguz and Minvielle (2001), Genchev et al. (2008), Tarhyel et al. (2012b), and Tarhyel et al. (2012a). Minvielle et al. (1999) and Sogut et al. (2015) stated that carcass characteristics of the wild-type group had relatively higher values, while Tarhyel et al. (2012b) reported that the white-colored group had significantly higher breast weight and thigh weight averages than the wild-type group, and differences between the carcass weights of the groups were not significant. Upon examining the effect of feather color differences on egg weight, shape index, specific gravity, shell weight, shell thickness, albumen weight, yolk weight, albumen index, and yolk index, the differences among groups were found to be significant $(\mathrm{P}<0.01, \mathrm{P}<0.05)$. In the light of the obtained results, it can be stated that the wild-type group had, in general, higher values relatively to other groups. There were no significant differences with regard to characteristics such as shell thickness and Haugh unit. Yilmaz and Çağlayan (2008) reported that the feather color had a significant effect on egg weight. They reported that the eggs from the white group weighed significantly less than those of the wild-type and brown groups, and that there were no significant differences between groups with regard to shape index.

Significant differences between fattening performances, carcass characteristics, and egg quality characteristics of Japanese quails with different feather color variations (white, dark brown, golden, and wild-type) were observed. When all characteristics were considered, none of color groups were superior to the others. Despite being superior to the other groups when comparing LW, the wild-type group loses its advantage for its higher feed conversion ratios. In spite of the lower live weight, other groups stand out for lower feed intake and feed conversion ratios (particularly the dark brown group). As a result of its higher live weight, the wild-type group naturally had higher values in certain carcass and egg quality characteristics. Other than the wild-type color, the lighter LW observed in the white, dark brown, and yellow-feathered quails than the wild- 
type quails was most likely due to recessive gene action. Researchers (Petek et al., 2004; Minvielle et al., 2007) have stated that recessive white color has a depressive effect on quail LW. However, more studies should be conducted for other colors to confirm that the recessive-gene action has a depressive effect on LW.

\section{Conclusions}

All four varieties of Japanese quail can be reared depending on the choice of the producer; as quails with white colored feather are especially preferred for meat production purposes, color variations should be considered when selecting Japanese quails. To determine the best color performance in the light of this study, more-intensive studies are required to investigate the basis for the effects of plumage color on quail performance.

\section{References}

Cheng, K. M. and M. Kimura. 1990. Mutations and major variants in Japanese quail. p.333-362. In: Poultry breeding and genetics. Crawford, R. D., ed. Elsevier, Amsterdam.

Crawford, R. D. 1990. Origin and history of poultry species. p.1-41. In: Poultry breeding and genetics. Crawford, R. D., ed. Elsevier, Amsterdam.

Erbaş, S. O. and Olmuş, H. 2006. Deney Düzenleri ve İstatistik Analizleri. Gazi Kitabevi, Ankara.

Fox, T. W. and Smyth, J. R. 1982. Further studies on the effects of the recessive white genotype on early growth rate and body size. Poultry Science 61:1585-1589.

Genchev, A.; Michavlov, G.; Ribanski, S.; Pavlov, A. and Kabakchiev, M. 2008. Meat quality and composition in Japanese quails. Trakia Journal of Sciences 6:72-82.

İnci, H.; Celik, S.; Sogut, B.; Sengul, T. and Karakaya, E. 2015. Figuring out the effects of different feather color on the characteristics of interior and exterior egg quality of Japanese quail by using Kruskal-Wallis Tests. Türk Tarım ve Doğa Bilimleri Dergisi 2:112-118.

Koçak, Ç. 1985. Bıldırcın üretimi. Ege Üniversitesi Zootekni Dergisi Yayınları, No:1. İzmir.

Marks, H. L. 1990. Genetic of egg production in other galli formes. p.761-770. In: Poultry breeding and genetic. Crawford, R. D., ed. Elsevier, Amsterdam, The Netherlands.

Marks, H. L. and Kiney, T. B. 1964. Measures of egg shell quality. Poultry Science 43:269-271.

Merat, P.; Bordas, F.; Jonon, F. and Perramon, A. 1981. Effets quantitatifs associés au gène albinos lié au sexe chez la caille japonaise. Annales de Génétique et de Sélection Animale 13:75-91.

Minvielle, F. 1998. Genetic and breeding of Japanese quail for production around the world. Proceedings of the 6th Asian Pacific Poultry Congress Nagoya, Japan.

Minvielle, F.; Hirigoyen, E. and Boulay, M. 1999. Associated effects of the Roux feather colour mutation on growth, carcass traits, egg production and reproduction of Japanese quail. Poultry Science 78:1479-1484.

Minvielle, F.; Gourichon, D. and Monvoisin, J. L. 2002. Testing homology of loci for two plumage colors, lavender and recessive white, with chicken and Japanese quail hybrids. Journal of Heredity 93:73-76.

Minvielle, F.; Gourichon, D. and Monvoisin, J. L. 2003. Effects of two-locus combinations, using the roux, lavender and beige mutation, on plumage color of Japanese quail. Journal of Heredity 94:517-522.

Minvielle, F.; Gourichon, D. and Moussu, C. 2005. Two new plumage mutations in the Japanese quail: "curly" feather and "rusty" plumage. BMC Genetics 6:14.

Minvielle, F.; Gourichon, D.; Ito, S.; Inoue-Murayama, M. and Rivie, S. 2007. Effects of the dominant lethal yellow mutation on reproduction, growth, feed consumption, body temperature, and body composition of the Japanese quail. Poultry Science 86:1646-1650.

Nakane, Y. and Tsudzuki, M. 1998. Clench: a new autosomal recessive mutation in Japanese quail. Journal of Heredity 89:347-348.

Narayan, N.; Agarwal, S. K.; Singh, B. P; Singh, D. P.; Majumdar, S. and Singh, R.V. 1998. Development of specialized strains of meat and egg type quails in hot climate. Proceedings of the 10th European Poultry Conference. Jerusalem, Israel.

NRC - National Research Council. 1994. Nutrient requirements of poultry. 9th rev. ed. National Research Council National Academy Press, Washington, D.C.

Oguz, I. and Minvielle, F. 2001. Effect of genetics and breeding on carcass and meat quality of Japanese quail: A review. p.63-68. In: Proceedings of 15th European Symposium on the Quality of Poultry Meat. WPSA Turkish Branch Kusadasi-Turkey.

Petek, M.; Ozen, Y. and Karakas, E. 2004. Effects of recessive white plumage colour mutation on hatchability and growth of quail hatched from breeders of different ages. British Poultry Science 45:769-774.

Roberts, C. W.; Fulton, J. E. and Barnes, C. R. 1978. Genetics of white-breasted, white and brown colors and descriptions of feather patterns in Japanese quail. Canadian Journal of Genetics and Cytology 20:1-8.

Robertson, W. B. R.; Bohren, B. B. and Warren, D. C. 1943. The inheritance of plumage color in the turkey. Journal of Heredity 34:246-256.

Somes, R. G. 1976. The genetic basis of several colour mutants of Japanese quail. Poultry Science 55:2094 (Abstract).

Somes, R.G. 1979. The genetic basis for feather colour patterns in four varieties of Japanese quail. Journal of Heredity 70:205-210.

Sogut, B.; Celik, S.; Inci, H.; Sengul, T. and Das, A. 2015. Figuring out the effects of different feather color weight on carcass characteristic of Japanese quail by using Friedman and Quade Tests of Non-Parametric Tests. Türk Tarım ve Doğa Bilimleri Dergisi 2:171-177.

Stadelman, W. J. 1986. The preservation of egg quality in shell eggs. p.63-73. In: Egg science and technology. Stadelman, W. J. and Cotteril, O. J, eds. Avi Publishing Company Inc., Westport, Connecticut, USA.

Tarhyel, R.; Tanimomo, B. K. and Hena, S. A. 2012a. Organ weight: As influenced by color, sex and weight group in Japanese quail. Scientific Journal of Animal Science 1:46-49.

Tarhyel, R.; Tanimomo, B. K. and Hena, S. A. 2012b. Effect of sex, colour and weight group on carcass characteristics of Japanese quail. Scientific Journal of Animal Science 1:22-27.

Truax, R. E. and Johnson, W. A. 1979. Genetics of feather colour mutants in Japanese quail. Poultry Science 58:1-9.

Tserveni-Gousi, A. S. 1987. Relationship between parental age, egg weight and hatching weight of Japanese quail. British Poultry Science 28:749-752.

Tsudzuki, M. 1995. Light down lethal: a new autosomal recessive down color mutation in Japanese quail. Journal of Heredity 86:305-307. 
Yannakopoulos, A. L. and Tserveni-Gousi, A. S. 1987. Effect of breeder quail age and egg weight on chick weight. Poultry Science 66:1558-1560.

Y1ldız, M. A. and Kesici, T. 1997. Japon bildırcınlarda (Coturnix coturnix japonica) sarı ve lekeli beyaz tüy rengini belirleyen genler arasındaki genetik ilişkinin incelenmesi. Lalahan Hayvancılık Araştırma Enstitüsü Dergisi 37:84-90.

Yıldız, M. A. and Kesici, T. 1999. Bıldırcınlarda kahverengi tüy renginin kalıtım analizi (Genetic analysis of brown feather colour in quail). Lalahan Hayvancıllk Araştırma Enstitüsü Dergisi 39:43-46.

Yıldız, N. 1983. Yumurtacı Ticari Hilmi Bir Tavuk Sürüsünde Bazı Verim Özellikleri ile ilgili Fenotipik Parametreler ve Yumurtlama Modeli. Doktora tezi. Elazı ̆.

Yılmaz, A. and Çağlayan, T. 2008. Farklı tüy rengine sahip Japon bıldırcınlarında (Coturnix coturnix japonica) yumurta ağırlığı, şekil indeksi ve çıkım ağırlığı ile bu özellikler arası ilişkiler. Fırat Üniversitesi Sağlık Bilimleri Veteriner Dergisi 22:5-8. 